\title{
Synthesis
}

\section{Understanding Human-Fire Interactions in Tropical Forest Regions: a Case for Interdisciplinary Research across the Natural and Social Sciences.}

\author{
$\underline{\text { Rachel Carmenta }}^{1,2}, \underline{\text { Luke Parry }}^{1}, \underline{\text { Alan Blackburn }}^{1}, \underline{\text { Saskia Vermeylen }}^{1}$, and $\underline{\text { Jos Barlow }}^{1}$
}

\begin{abstract}
Fire in the forested tropics has profound environmental, economic, and social impacts at multiple geographical scales. Causes of tropical fires are widely documented, although research contributions are from many disciplines, and each tends to focus on specific facets of a research problem, which might limit understanding of fire as a complex social-ecological system. We conducted a systematic review to (1) examine geographic and methodological focus in tropical fire research; (2) identify which types of landholders are the focus of the research effort; (3) test for a research method effect on the variables, e.g., socio-political, economic, and climatic, identified as causes of and proposed management solutions to tropical fire; and (4) examine relationships between causal factors and proposed solutions. Results from 51 studies show distinct geographic and methodological tendencies in the literature. Few studies explicitly identify landholder types, and no social studies focused on large-landholders. Multiple drivers and potential solutions to preventing fire are identified and the research approach adopted had the strongest influence on the socioeconomic, direct fire management and landscape characteristics variables. There was an overall mismatch between identified cause and proposed management solution. These findings indicate that mixed method approaches are imperative to understanding the coupled human-nature system of fire and to improve rural development and management strategies to curtail tropical fire spread.
\end{abstract}

Key Words: fire management; interdisciplinary research; multiscale analysis; scale-pattern-process; social-ecological systems; tropical forests

\section{INTRODUCTION}

Fire is widely used in tropical land conversion and regrowth removal (Malingreau and Tucker 1988, Eva and Lambin 2000, Aragão et al. 2008) because it is an economically attractive management tool to farmers lacking access to machinery or fertilizer and pesticides (Pyne 2001). Consequently, fire management helps support 300 million of the world's forest-based poor (Brady 1996), in addition to hundreds if not thousands of cattle ranchers and industrial-scale farmers. Fire use and management throughout the tropics is diverse and context dependent. In savannah and wetland systems, indigenous fire management plays an important role in maintaining ecosystem services (Bird et al. 2008, McGregor et al. 2010) and preventing large-scale catastrophic fires, and is increasingly integrated with land management strategies. This review is restricted to tropical humid forests where fire is both an important agricultural tool and a major driver of global environmental change (Bowman et al. 2009). For example, over one-quarter of the Brazilian Amazon is estimated to be at risk from fire because of proximate ignition sources (Barreto et al. 2006) and extensive areas have been affected by accidental fires in Indonesia (Tacconi et al. 2007). The spread of fire in tropical forest landscapes presents a significant threat to human well-being (Nepstad et al. 1999a), biodiversity (Barlow and Peres 2006), above ground carbon storage (IPCC 2007), carbon mitigation mechanisms (Aragão and Shimabukuro 2010), and ultimately climate regulation (Betts et al. 2004, Foley et al. 2007). Given the severity of the issue, it is vitally important to understand the causes of tropical fires, as well as identify potential solutions to fire management and reduce accidental fire spread. Such research can guide policy and 
practices of sustainable forest management while minimizing the extraneous costs of fire to society and the environment.

The complexity of the problem makes the development of suitable fire management policy challenging. The majority of fires are initiated by human action, and the fire system is the product of social, economic, and biophysical factors operating with feedbacks and interactions across spatial scales (Eva and Lambin 2000, Dennis et al. 2005, Sorrensen 2009). Climatic factors such as El Niño episodes and drought interact with logging and forest fragmentation to influence fire spread (Alencar et al. 2006, Aragão et al. 2008, Cochrane and Laurance 2008). Furthermore, fire use and fire management decisions are made locally and are influenced by social norms including folklore, and interactions (Mistry 1998). However, these local choices are in turn affected by remote structural factors such as regional and national environmental policies, which are themselves influenced by the global community (Sorrensen 2004, Nepstad et al. 2006, Wilbanks 2006).

A wide range of research approaches have been applied to the study of fire in the tropical forest biome. These include the natural and social sciences, quantitative and qualitative approaches, and positivist and nonpositivist perspectives. Natural scientists have focused on the remote observation of fire patterns, and the local environmental impacts of these fires. The remote sensing community relies on satellite-derived data, acquired via reflectance values of wavelengths of energy from the earth's surface and used to detect and monitor "hot spots" (Stolle et al. 2004). They aim to determine the predictors of fire through statistical models and increasingly combine remotely sensed data with secondary socioeconomic or political data (Roman-Cuesta et al. 2003, Stolle and Lambin 2003, Alencar et al. 2004, Nepstad et al. 2006, Adeney et al. 2009). Ecologists tend to work at smaller scales and have addressed issues such as the effects of fire on tree mortality and species diversity (Slik et al. 2002, Barlow and Peres 2006).

Social scientists interested in tropical fire also differ in their approaches and scales of study. Large-scale economic analyses have been used to determine the costs incurred during fire episodes in Indonesia and the Amazon (Varma 2003, de Mendonça et al. 2004), and to model future fire activity under a range of scenarios (Arima et al. 2007). Field-based social studies range from quantitative research utilizing household surveys to analyze the household determinants of fire use and management (Bowman et al. 2008), to decision making analysis using openended interviews (Mistry 1998). Other social approaches include ethnographic methods combined with a political ecological framework (Kull 2002a) or critical geography perspectives (Harwell 2000) to understand the causes and potential management solutions to forest fires. The anthropological literature has also examined indigenous fire use and management and has focused on the role it plays in making specific changes to vegetation communities (Posey 1985, Bird et al. 2008).

Fully integrated approaches to fire research have emerged in recent years. Mixed methods studies integrate geospatial technologies with various social and participatory methods and often address multiple spatial, institutional, and temporal scales (Giri and Shrestha 2000, Simmons et al. 2004, Dennis et al. 2005). Mixed methods have been used to focus on the role of fire in land cover change (Sorrensen 2004), the interplay of property rights, i.e., communal vs. private, in fire management (Toniolo 2004), and to understand the nuanced cultural dynamics behind fire patterns (Dennis et al. 2005). However, integrated approaches to population and environment evident in other fields of research (for example, see listings of integrated studies on nature-environment systems at http://hdg c.epp.cmu.edu/projects/projects.html), particularly in the land use change literature (Liverman et al. 1998, Perz and Walker 2002, Caviglia-Harris and Harris 2008), are currently rare in the fire literature.

Because disciplines tend to focus on specific types of variables and scales of analysis, there is a potential for research results to, in part, be artifacts of the research approach (Reid et al. 2006). Research approach bias could also mean that (1) causes and solutions to tropical fire are identified as significant while many other variables go unmeasured, and (2) that the relative frequencies of cause and management solution are not indicative of their importance. The potential biases of disciplinary and multidisciplinary fire research in the tropics have not been evaluated. Such an analysis is necessary because the type of research approach adopted could be influencing results and limiting our understanding of the fire system, and our ability to identify effective and pragmatic management solutions. We conduct a systematic review to 
examine where research has been taking place, which landholder types, e.g., cattle rancher or smallholder, have been the focus of the various studies, which methods have been applied, and which variables have been identified. A systematic review enables triangulation, i.e., cross-checking, among approaches and offers insights not obtainable from an analysis of any one study alone (Jick 1979, Pullin and Stewart 2006). Specifically we address the following research questions: (1) How does the number of fire research studies vary i) geographically, across regions, and ii) methodologically, in approach?; (2) Do different research approaches i) focus on different landholders, ii) identify different causal factors for fire, and iii) propose different solutions?; (3) Is there a discrepancy between the causal factors and the proposed management solutions that are identified? We address each of our key research findings and consider their policy implications. We then combine observations from the fire literature with insights derived from studies on land use and land use change (LUCC) to identify priorities for future research.

\section{METHODS}

A systematic review is possible after a series of decisions are taken on categorizing the information within studies (Rudel 2008). Such categorization generates two potential avenues for error associated with subjectivity. Readers may (1) infer disparate causality and solution variables from the same academic work, and (2) attribute those variables to different categories. Although this error is largely standardized in this review, because the data were classified by one person, it is possible that in some cases our interpretation may not reflect the original authors' opinions. The analysis was conducted based on the following set of definitions and criteria.

\section{Defining fire management, research approach, and landholders}

We based our review on a key word search in the ISI Web of knowledge (fire management and tropical forest*), selecting from journal article publications only (first record dated 1978), for all years and augmenting the hits returned $(n=378)$ with papers known to the authors $(n=30)$. From an initial list of 408 papers, we selected those papers that attempted to identify causality related to the frequency and extent of fire (shortlist $n=51$ ), and that we therefore considered were relevant for fire management.

From a review of all short listed papers, we identified four main groups of research approach. These were (1) Remote; authors use remote sensing or combine remote sensing with secondary data plus one paper in which authors use secondary spatial data, e.g., census data, only; (2) Social; papers based on the collection of some form of field-based social data in their research, either stand-alone or in combination with secondary data; (3) Mixed method approach; authors combine remotely sensed or secondary data with field-based social data; and (4) Review; including review papers, and including overview papers in the social sciences.

To investigate the types of landholders on which research approaches focus, we used the two largest geographical subsets of the papers, one from the Brazilian Amazon and the other from Indonesia. In both subsets we classified landholders into two main groups: large landholders and smallholders. We did not include other actors such as government officials and policy makers because we were specifically interested in the dynamics of the landholders, i.e., fire starters, themselves. Five studies from Indonesia include both large and smallholders in a single study, and thus these studies were counted once for each group.

\section{Extracting variables and defining categories of variable membership}

For each study, we recorded all variables that were found to be significant causal drivers of forest fire spread and fire extent. For quantitative papers, these were the statistically significant factors, whereas for qualitative approaches, we included the factors authors identified with a causal role. The proposed management solutions were extracted from each paper, regardless of whether they were evidencebased, i.e., had been analyzed as potential fire cause in the study. Fire causes and management solutions were numerous and varied. Their range included meteorological conditions such as humidity and rainfall (e.g., Alencar et al. 2006); market conditions such as the price of beef (e.g., Arima et al. 2007); and institutional factors such as securing the property rights regime (e.g., Dennis et al. 2005). We developed eight categories to group the variables: socio-political (SP); climatic (C); forest type and quality (FTQ); economic (E); landscape context 
Table 1. Category definition used to group the factors and solutions related to fire extent and management.

\begin{tabular}{ll}
\hline \hline Category (abbreviation) & Definition (and examples) \\
\hline Socio-political (SP) & $\begin{array}{l}\text { Social, cultural, and demographic variables, e.g., time on plot, attitudes, } \\
\text { population density, and factors related to institutions and political variables, } \\
\text { e.g., land tenure and state. }\end{array}$ \\
Climatic (C) & Meteorological and climatic conditions, e.g., season, rainfall, temperature. \\
Forest type and quality (FTQ) & $\begin{array}{l}\text { Factors related to human induced attributes and ecological conditions of } \\
\text { forest, e.g., forest degradation and biomass density. }\end{array}$ \\
Landscape context (LC) & $\begin{array}{l}\text { Concerned with the landscape at the regional scale. It includes variables that } \\
\text { relate to the landscape in terms of its natural and human influenced attributes, } \\
\text { including distance functions of demographic variables, e.g., distance to roads } \\
\text { or rivers, soil quality. It does not include variables specifically relevant to } \\
\text { forest type and quality nor to economic or socio-political factors. }\end{array}$
\end{tabular}

Economic (E)

All variables related to markets and economic structures and conditions, e.g., price of beef and GDP.

Technological and research (TR)

The technological aspects linked to fire, e.g., detection capabilities, and those related to research, e.g., standardizing approaches, improving fire modeling.

Fire management (FM)

Factors explicitly related to direct fire management, e.g., fire safety training and local fire management.

Fire characteristics (FC)

Intrinsic properties of fire, e.g., anonymity and self-propagation.

(LC); technological and research (TR); direct fire management (DFM); and fire characteristics (FC). Each category includes factors at multiple spatial scales (See Appendix). For example, within the socio-political category, variables range from the international level, e.g., international aid, national level, e.g., fire legislation, state level, e.g., land tenure security, and community level, e.g., education and awareness. Although scaling up to the category level masks considerable variation, it is a good starting point for important comparison among approaches. Definitions and examples are provided in Table 1 .

\section{Matching the causal factor and proposed management solution}

To investigate the relationship between fire cause and management solution in each category, we created three groups. For each of the eight categories we recorded whether a paper included it as (1) a fire cause but not a proposed management solution; (2) a proposed management solution but not a fire cause; and (3) a fire cause and a proposed management solution. Finally, we analyzed the proportion of total studies from each research approach, i.e., remote, social, mixed, and review, within each of the three groups.

\section{Data analysis}

Statistical analysis was conducted in the package $\mathrm{R}$ version 2.10.1 (R Development Core Team). Our data were proportion data, with vectors bound between 1 and 0 and therefore we assumed binomial error structure. The appropriateness of the assumption of binomial errors was checked by comparing the residual deviance with the residual degrees of freedom after fitting the explanatory variable. To test for a research method effect on the categories identified as (1) causal factors and (2) proposed management solutions while accounting for the data type, we used a general linear model Analysis of Deviance (Crawley 2007). Significance 
Table 2. Number of papers per research approach category for Brazil, Indonesia, and all countries combined.

\begin{tabular}{|c|c|c|c|c|}
\hline \multirow[t]{2}{*}{ Country } & \multicolumn{4}{|c|}{ Research approach (papers) } \\
\hline & Remote & Social & Mixed method & Review \\
\hline Brazil & 7 & 2 & 6 & 1 \\
\hline Indonesia & 4 & 4 & 3 & 6 \\
\hline Other & 10 & 5 & etc & \\
\hline Total & $21\left(1-21^{\dagger}\right)$ & $11\left(22-32^{\ddagger}\right)$ & $11\left(33-43^{\S}\right)$ & $8\left(44-51^{1}\right)$ \\
\hline
\end{tabular}

1-21: (1) Eva and Lambin 2000; (2) Kant et al. 2000; (3) Elvidge et al. 2001; (4) Nepstad et al. 2001; (5) Bucini and Lambin 2002; (6) Cardoso et al. 2003; (7) Roman-Cuesta et al. 2003; (8) Stolle et al. 2003; (9) Stolle and Lambin 2003; (10) Stolle et al. 2004; (11) Dymond et al. 2005; (12) Chand et al. 2006; (13) Nepstad et al. 2006; (14) Roman-Cuesta and Martinez-Vilalta 2006; (15) Arima et al. 2007; (16) Phua et al. 2007; (17) Wright et al. 2007; (18) Aragão et al. 2008; (19) Prasad et al. 2008; (20) Vadrevu et al. 2008; (21) Adeney et al. 2009.

$¥$ 22-32: (22) Harwell 2000; (23)Bruner et al. 2001; (24) Kull 2002a; (25) Kull 2002b; (26) Kull 2002c; (27) Sorrensen 2002; (28) Murdiyarso et al. 2004; (29) Suyanto et al. 2005; (30) Tacconi and Ruchiat 2006; (31) Suyanto 2007; (32) Brondizio and Moran 2008.

$\S 33-43$ : (33) Nepstad et al. 1999b; (34) Giri and Shrestha 2000; (35) Sorrensen 2000; (36) Cochrane 2001; (37) Alencar et al. 2004; (38) Hoare 2004; (39) Simmons et al. 2004; (40) Chokkalingam et al. 2005; (41) Dennis et al. 2005; (42) Alencar et al. 2006; (43) Chokkalingam et al. 2007.

I 44-51: (44) Malingreau et al. 1985; (45) Aiken 2004; (46) Vayda 2006; (47) Lohman et al. 2007; (48) Murdiyarso and Lebel 2007; (49) Tacconi et al. 2007; (50) Cochrane and Laurance 2008; (51) Sorrensen 2009.

testing was performed with $\chi^{2}$ tests. We considered $P<0.5$ to be statistically significant for all statistical tests. We used descriptive analysis of trends where small sample size prevented us from applying statistical tests.

\section{RESULTS}

\section{Geographic distribution and research approach}

We reviewed 51 articles, $33(65 \%)$ of which were based on research from just two countries, the Brazilian Amazon $(n=16)$ and Indonesia $(n=17)$. The 18 additional studies included research-based in non-Brazilian Amazon basin $(\mathrm{n}=1)$, Central African Republic $(n=1)$, global papers $(n=3)$, India $(n=4)$, Madagascar $(n=3)$, Malaysia $(n=1)$, Mexico $(n=2)$, Southeast Asia $(n=1)$, and Thailand $(n=2)$.
The remote research approach dominated in $41 \%$ of the reviewed publications. Of the remaining papers, $22 \%$ employed a social approach, $22 \%$ a mixed methods approach, and $16 \%$ of them were reviews. In Indonesia, the research effort has been more evenly spread among the various approaches, whereas the research in Brazil has been dominated by remote and mixed method approaches (Table 2 ).

\section{Causal factors and proposed management solutions}

The most frequently cited causes of fire were sociopolitical, climatic, and forest type and forest quality (Fig. 1). Research approach appears to influence the factors attributed with causality of fire significantly in two instances. First, the socio-political category, e.g., including variables such as land tenure and state/province membership, was identified as a significant cause of fire by $100 \%$ of the social 
studies, $75 \%$ of review approaches, and by just half of the research papers that used remote $(52 \%)$ and mixed methods (55\%; Fig. 2 ; df $=3, \chi^{2}=11.7, \mathrm{P}=$ 0.003). Second, direct fire management, e.g., status of fire management plans and availability of advance climatic information, was identified as a cause of fire by around half of the review (45\%) and social papers $(50 \%)$, just $18 \%$ of the mixed method studies, and was wholly absent from remote approaches ( $0 \%$; Fig. $\left.2 ; \mathrm{df}=3, \chi^{2}=16.5, \mathrm{P}=0.001\right)$.

Proposed management solutions to reducing fire impacts were more socio-political and technological in nature than the cited fire causes (Fig. 1). Research approach appears to influence the management solutions identified in two of the eight categories (Fig. 2). First, the socio-political category, e.g., solutions such as strengthening community institutions or adapting current legislation, was consistently identified by the social approaches $(100 \%)$, often by review $(75 \%)$, but less frequently by mixed methods (57\%) and remote research approaches (55\%; df $\left.=3, \chi^{2}=10.6, P=0.006\right)$. Second, landscape context solutions, such as halting road expansion, were dominated by mixed method studies (45\%), while the social remote and review papers identified them far less frequently $(0 \%, 10 \%$, $13 \%$, respectively; $\mathrm{df}=3, \chi^{2}=9.9, \mathrm{P}=0.02$ ).

\section{Matching causal factors and proposed solutions}

Several variable categories were frequently identified as a management solution and far less frequently identified as a fire cause (Fig. 3). For example, direct fire management was a commonly cited management solution, e.g., solutions such as fire safety training and local fire management, while causes related to direct fire management were few. The technological and research presence in the "management solution not fire cause" group warrants some explanation. Technological and research failings were associated with some blame in increasing fire extent, but far more frequently this category is given as a potential management solution, e.g., via improving detection capabilities and increasing research on the human dimensions of fire. Other common categories in the "management solution not fire cause" group were economic, e.g., providing economic incentives, and landscape context, e.g., halting road expansion, which were mostly from the remote and the mixed method studies. Variable categories frequently cited as a "fire cause and management solution" were socio-political, e.g., tenure security, and economic, e.g., economic incentives, which were most often from the social studies. Some categories were often identified as a fire cause but the inverse was not proposed as a management solution. Forest type and quality, e.g., causes such as biomass density and logging, and landscape context, e.g., causes such large landholder presence and distance to a populated place, were often within this group. Two categories were always in the "fire cause not management solution" group; they were climate, e.g., causes such as temperature, humidity, and rainfall, and fire characteristics, which are variables attributed to the nature of fire itself, e.g., its selfpropagation that ensures fires can be lit anonymously.

\section{Landholders}

We used studies from the Brazilian Amazon ( $\mathrm{n}=$ 16) and Indonesia $(n=17)$ to examine whether different research approaches focused on particular groups of landholders. Patterns were distinct for each country and Brazil tended to have a more highly pronounced research method actor bias (Fig. $4)$. Only $31 \%(n=11)$ of studies in Brazil identified actors, of these smallholders were most commonly studied $(\mathrm{n}=4)$. In Indonesia, a similar proportion of studies identified actors (39\%) but the focus tended to be dual, on both large and small landholders (Fig. 5). In both countries the majority of studies (Brazil $=69 \%$, Indonesia $=65 \%)$ did not identify the actors. The remote $(73 \%)$ and review $(100 \%)$ research approaches had the highest proportion of not identified actors. In both countries large landholders received little explicit attention $($ Brazil $=6 \%$, Indonesia $=0 \%)$.

\section{DISCUSSION}

Our results demonstrate that efforts to understand the causal drivers and potential management solutions to tropical forest fires may be constrained by the limitations of different research approaches. Fire hazard involves economic, socio-political, and biophysical factors at different spatial, institutional, and temporal scales. This complexity is typical of other social-ecological systems (Liu et al.2007) and environmental management issues, such as the 
Fig. 1. Proportion of total number of studies identifying the causal factor and solution categories (SP socio-political; C - climatic; FTQ - forest type and quality; E - economic; LC - landscape context; TR - technological and research; FM - direct fire management; FC - fire characteristics), all methods combined.

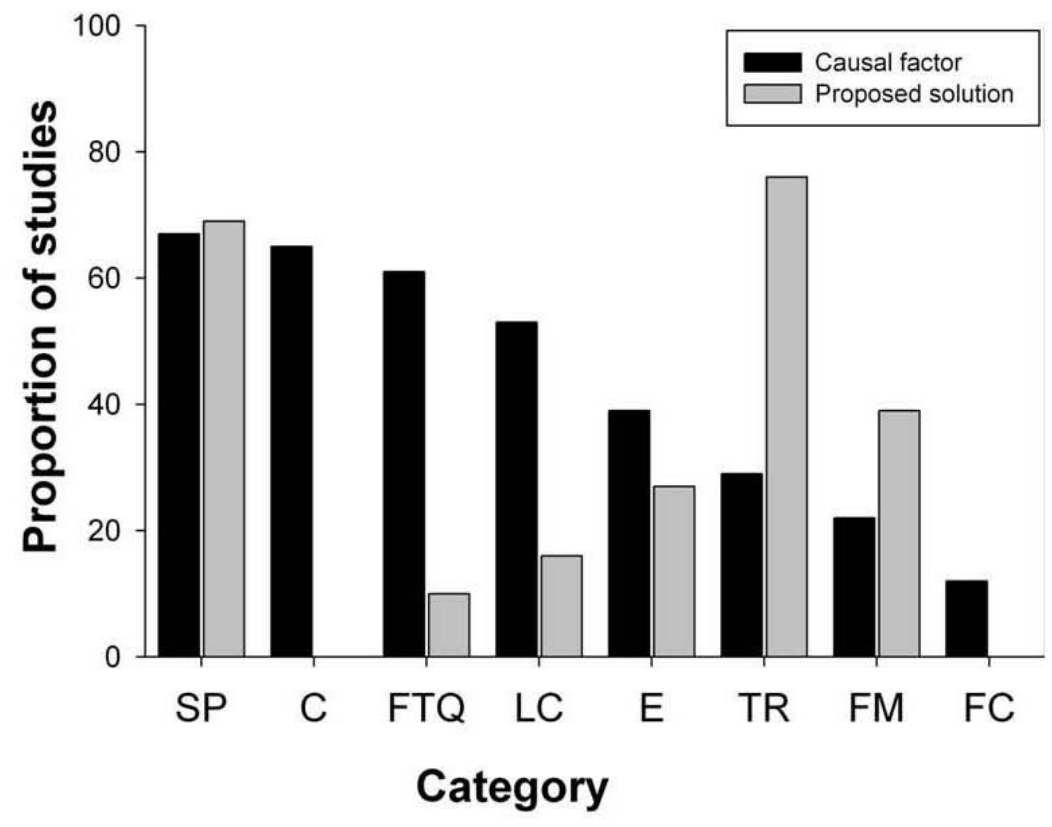

drivers of land use change (Giest and Lambin 2001, Walsh et al. 2008), community forest management (Pagdee et al. 2006), and climate change (Kates and Wilbanks 2003). Here we address the key discussion points for each of our research questions and argue that the complexity of the fire system warrants an interdisciplinary research approach. We combine our results with insights derived from the land use and land cover change (LUCC) literature and present recommendations to guide future research.

We found distinct geographic, methodological, and landholder biases in 51 papers that we reviewed. Tropical forest fire research has focused almost exclusively on two of the three countries containing the highest tropical forest cover, Brazil and Indonesia, both of which have significant fire problems. Although it is important to understand the dynamics of tropical fire in these countries, important contextual insights that vary regionally may be poorly represented. One merit of countryspecific studies, particularly those that can include the regional and local scales and adopt an integrated approach, is their ability to identify contextual factors, i.e., social, economic, cultural, and ecological, which can be pivotal to outcomes and vary from location to location (e.g., Kull 2002b, Dennis et al. 2005). Future research should prioritize tropical countries such as Zambia, Madagascar, and India that are experiencing high levels of fire (Flannigan et al. 2009) yet are underrepresented in the literature, although may exist in the grey or non-English literature. In addition, research traditions between Brazil and Indonesia are relatively distinct. Remote approaches are most common in Brazil, which has a history of using technology to monitor changes in land cover and land use, e.g., Brazil's rapid deforestationdetection system (INPE 2009). Indonesia has a relatively more even distribution between the various research approaches. We have shown that these research traditions are likely to be influencing the types of drivers and solutions identified in these countries. 
Fig. 2. Proportion of research approach and the categories (SP - socio-political; C - climatic; FTQ forest type and quality; E - economic; LC - landscape context; TR - technological and research; FM direct fire management; FC - fire characteristics) they identify as i) causal factors for fire, and ii) proposed management solutions. Significance values of results of analysis of variance to test for significant differences between research methods within category expressed as: $* * *=<0.001$; $* *=<$ $0.01 ; *=<0.05$.

\section{Causal factors}

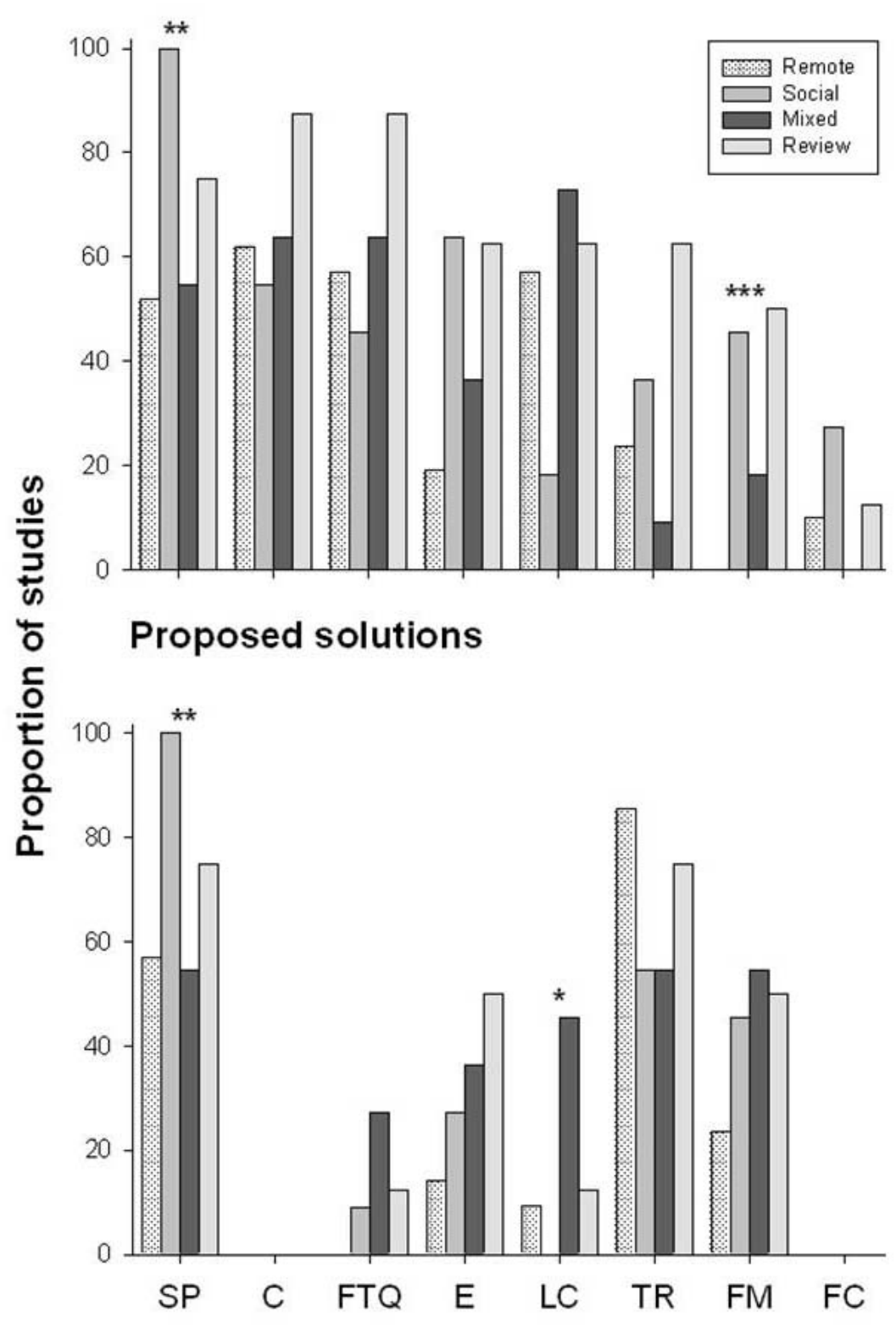


Fig. 3. Proportion of studies citing each category in relationship to a) Those that identify the category as a causal factor and not a proposed management solution; b) a management solution but not a causal factor; c) a causal factor and a proposed management solution. $\mathrm{N}$ studies is given on the right of each graph.

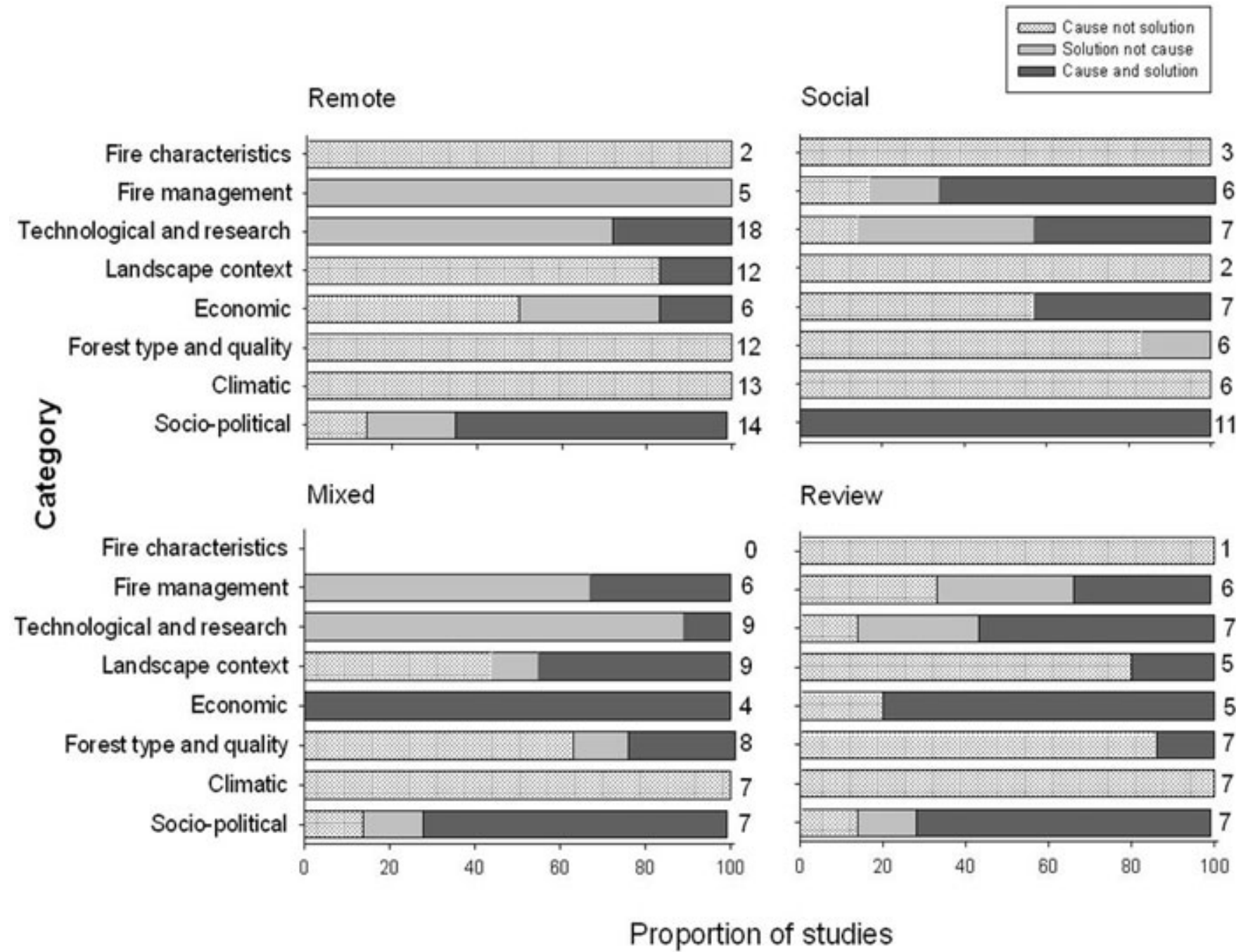

Our review demonstrates that current understanding of tropical fire is also hampered by the limited number of social and mixed method studies. Remote approaches are often favored by resource managers, policy makers, and the courts because of their replicability and representation of a seemingly objective reality (Harwell 2000; R. Rajão, personal communication). Remote sensing studies tend to determine fire causality via spatial correlations or regressions of hot spot occurrence with secondary data, such as: gross domestic product or human population density (Roman-Cuesta et al. 2003); distance to a feature such as a road; a reserve polygon, or its buffer area (Stolle et al. 2003, Nepstad et al. 2006, Adeney et al. 2009). Although effective at broad scales, the coarse resolution of secondary data often prevents these studies from moving beyond generalizations (Wood and Skole 1998, Wilbanks 2006). For example, although remote sensing might show that protected areas 
Fig. 4. Actor focus of the different research approaches, using studies from Brazil. The thickness of the lines linking the shapes represent the percentage of studies focusing on each actor group.

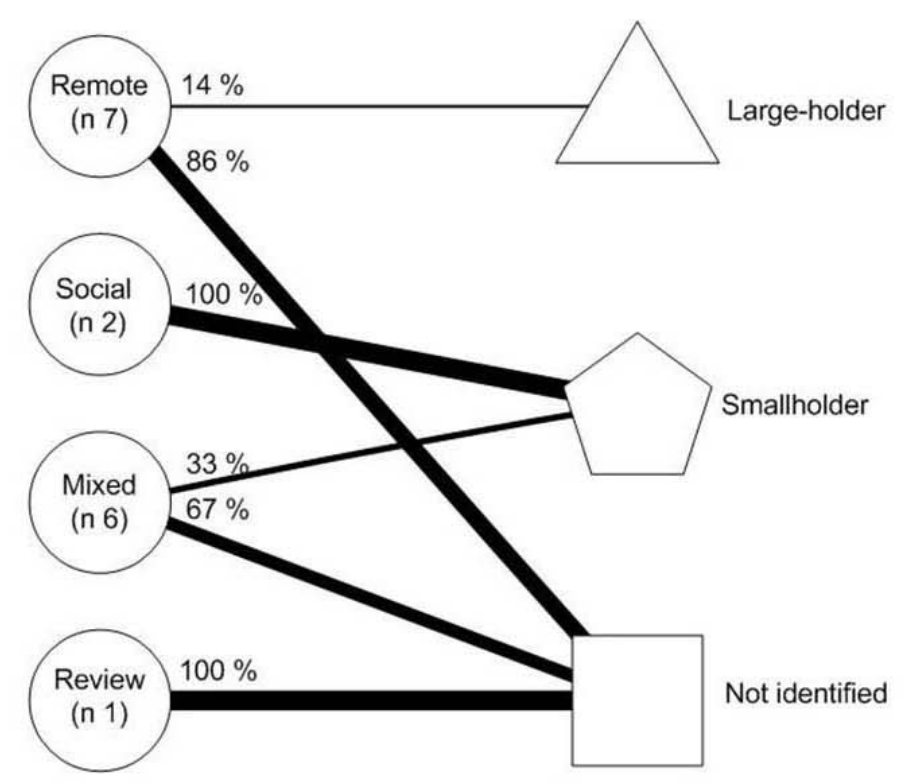

affect the frequency of fire, the social mechanisms and household determinants of the change can only be inferred (Crews and Walsh 2009).

We found that the majority of existing studies did not explicitly identify landholders, yet almost all fire in tropical forests is caused by people, and local agents therefore play a significant role in the system (Giri and Shrestha 2000, Kull 2002a). Remote sensing studies rarely identify actors. Social studies are more actor-specific, but almost always focus on smallholders. Social studies focusing explicitly on large landholdings, e.g., cattle ranches or plantations, are almost nonexistent, even though cattle ranchers are responsible for $\sim 70 \%$ of all deforestation in the Brazilian Amazon (Fearnside 2005) and a significant portion of the ignition sources (Uhl and Buschbacher 1985). The lack of landholder-specific information is important because differences in household characteristics determine distinct patterns of environmental change and drivers differ between households (Pichon 1997, McCracken et al. 1999, Pan et al. 2004). The social, economic, and cultural differences between small and large landholder systems (Walker et al. 2000) imply that these landholder groups will be associated with different patterns of fire use and management. Landholder-specific differences must be understood if sustainable governance strategies to instigate change in local level management are to be targeted, adapted, and integrated from local to national levels, connecting actors and institutions (Folke et al. 2005, Berkes 2006, Olsson et al. 2006, Boyd 2008).

The biases of research traditions are reflected in their tendency to measure certain variables while ignoring others, which can weaken the understanding of complex systems (Jick 1979, Reid et al. 2006). It was therefore surprising to observe that research approaches cover many of the same categories of drivers and proposed management solutions. For example, the climatic, economic, and forest type and forest quality categories were indicated as significant fire causes and management solutions across research approaches. However, our analysis indicates that in some instances research approach does influence results, implying that particular approaches are tied to certain categories of causes and solutions. For example, the sociopolitical category was cited significantly more frequently, as both a fire cause and a management 
Fig. 5. Actor focus of the different research approaches, using studies from Indonesia. The thickness of the lines linking the shapes represent the percentage of studies focusing on each actor group.

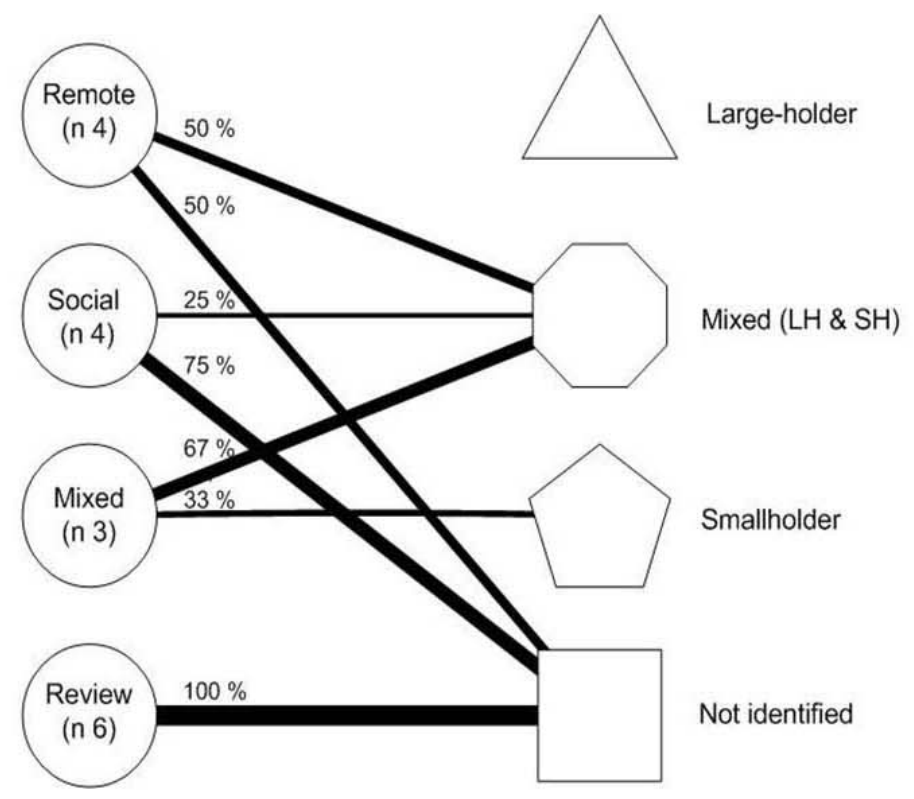

solution, by the social approaches than by the remote, mixed method, and review approaches. In this instance, the bias makes it difficult to evaluate the importance of socio-political factors as drivers of fire or as potential management solutions. Research approach bias was also identified in the direct fire management and technological categories.

Although our results highlight some of the biases in fire research, it is important to note that alternative explanations may exist for these patterns. For example, perhaps all causal drivers and potential solutions are important in some instance, but act synergistically and particular research approaches are better able to interpret certain facets of the problem or solution. Irrespective of the possible reason for bias, a triangulated mixed method research design would help to fully understand tropical fire. This approach can correct for potential biases if the identification of drivers and solutions are artifacts of approach. Alternatively, it would help to elucidate complex synergies taking place if the fire causes and solutions are multifaceted.

\section{Comparing the causes and solutions of fire}

The incongruence between fire causes and management solutions proposed by researchers reflects the complex and spatially scaled interactions of cause and effect in coupled humanenvironment systems (Wilbanks 2006) and further highlights the need for interdisciplinary research designs. It suggests that an environmental domain, such as forest type and quality, can in part be rectified by social processes or market incentives, by identifying one as the cause and the other as the solution. A distinct and common relationship that we found was the "management solution not fire cause" group. The mismatch might be because a given fire cause variable was not found to be significant in a study and so was not included in our analysis. A more alarming explanation could be that solutions are recommended without being evidence-based. The direct fire management and technological and research categories were most often in the "management solution not fire cause" group. This raises concern as direct fire management is clearly considered an important solution to the fire hazard, yet remains poorly 
studied (Mistry 1998, Bowman et al. 2008). Furthermore, reliance on technological advances as a solution to fire will only be successful if institutional frameworks can incorporate sensitivity to local level constraints (Rajão and Hayes 2009) such as access to machinery or man power and norms of behavior. Obviously some factors contributing to tropical fire spread are beyond the scope and time scale of local governments and individuals to tackle and so are not recommended by the authors. For example, the climatic category was often identified as a cause of fire, but was never proposed as a solution. We found the mixed method research group provided the majority of solutions that were also identified as a cause (Fig. 3), supporting the need for integrated fire research designs.

\section{Future research and policy implications}

A mixed method approach is argued to be the third grand research paradigm (Johnson et al. 2007). Arguments for combining qualitative and quantitative approaches to understanding human behavior and the added value of multidisciplinary studies are long-standing (Jick 1979, Blaikie 2000, Olsen 2004). Triangulation among approaches is a form of validation and also a means to extend and amplify current knowledge by obtaining information on different facets of the research problem (Olsen 2004). The suitability of a mixed method approach is pronounced for coupled human-natural systems that involve human decision making and the natural environment (Berkes 2004, Frost et al. 2006, Wilbanks 2006, Ostrom 2007). Mixed method research may be conducted at different scales. One illustrative example comes from Ostrom and Nagendra (2006) who combine satellite data, e.g., forest expansion and contraction, social and ecological ground data, e.g., forest density and rule monitoring behavior of the local population, with laboratory-based data, e.g., human decision making, to assess how institutional and tenure arrangements effect forest cover. The utility of mixed method approaches involves their ability to capture a range of significant variables, e.g., sociopolitical, economic, and environmental, and has been demonstrated by the LUCC community (Asner et al. 2006, Turner et al. 2007, Walsh et al. 2008) that emerged following Liverman et al. (1998). LUCC research frequently links place-based data, e.g., ethnography and interviews, to remotely sensed data, e.g., land use, to identify the multiple determinants of land use change and degradation in tropical forests. Economic factors, e.g., gate price of agricultural products; social factors, e.g., age of head of household; geographic factors, e.g., distance to road; and biophysical factors, e.g., remaining forest cover on property, form complex relationships that would not be detected with a mono-disciplinary research design (McCracken et al. 1999, Rindfuss et al. 2003).

In many ways, fire is as complex as LUCC, as demonstrated by the multiple categories, e.g., sociopolitical, economic, and climatic, involved in determining and containing the fire hazard (e.g., Kull 2002c, Alencar et al. 2004, Simmons et al. 2004, Aragão et al. 2008). Disciplinary research approaches are important because they can contribute detailed data on specific elements of the complex. However, triangulated analysis, such as those found in the LUCC literature, enable scrutiny of the relevance and modes of influence of different fire cause and fire management variables and the impact of a given variable at different scales (Smucker et al. 2007). One exemplar study was undertaken by Dennis et al. (2005) who used social research methods, including stakeholder interviews, ethnography, surveys, and participatory mapping, and geospatial analysis, including multitemporal series of remotely sensed imagery and hot spot analysis, in a hybrid of research methods addressing multiple scales and multiple locations. They were able to develop detailed histories of fire impacts and landscape changes in these areas and inform them with contextual information from local through to government levels. The research produced targeted, context-specific policy recommendations and confirmed the inadequacy of "one size fits all" solutions and blanket bans.

It is clear that there have been insufficient groundbased studies, i.e., surveys, ethnography, and participatory methods, of the determinants of fire use and management solutions, e.g., time spent building fire breaks, etc. They represent a poignant omission (Nepstad et al. 1999a, Aragão and Shimabukuro 2010) because ground surveys capture social and local level data and can effectively identify key factors in fire management decision making. These insights can be used to inform strategies to reduce the damaging ecological and social consequences of accidental wildfires as well as to understand the benefits and cultural 
significance of using fire. Field research can differentiate between the multiple landholders, and between intentional and accidental fire, unlike remote approaches. We found only one paper that included information on the local beliefs for the increased fire incidence in the area (Harwell 2000) suggesting there is much room for incorporating a participatory element to the current research. Further analysis of the different spatial, institutional, and temporal scales identified within the variable categories would help guide policy and management strategies to reduce fire impacts. Research in areas such as ethnopedology, which combines natural and social sciences to understand local traditional and modern soil knowledge systems, has illustrated the merits of combining topdown and bottom-up management for sustainable resource use and targeting research and development activities (Barrera-Bassols et al. 2006). Studies of traditional fire management in savannah and wetland systems show how such management can be important to maintain biodiversity by acting as an intermediate disturbance (Bird et al. 2008, McGregor et al. 2010).

Our research offers insights as to why the zero burn policies of various tropical regions such as those in Madagascar (Kull 2002c) and Indonesia (Tacconi et al. 2007), and parts of Brazilian Amazonia, are not enforced, nor adhered to. Given the complexity of the fire system, "cure-all" policy instruments are unlikely to be effective (Ostrom et al. 2007) although they are repeatedly attempted. The lack of contextual social data in the literature hinders the formulation of management strategies that are aligned to the local reality (Hayes and Rajão 2011). Burn bans in Brazilian Amazonia, which are sometimes triggered by peaks in satellite-based hot spot detection (Carvelheiro 2004), situate the fire problem as a relatively instant crisis and thus divert attention from the fundamental development issues that create the need for fire use (Simmons et al. 2004). In Madagascar, the ban has created a stalemate where local people are highly secretive about their actions (Kull 2002b). In Brazil, fire management rules codified in legislation are not credible nor deemed legitimate by local communities because they incorporate little to no local knowledge nor are they sensitive to the obstacles and restraints faced by local communities (Carvelheiro 2004). Understanding the rationale of agricultural practices, the limitations experienced by farming households, and the knowledge systems and social institutions that they are part of can aid management. By involving local stakeholders, the resultant solution strategies are more likely to be practically relevant, perceived as legitimate, and hence adhered to at the local level (Ostrom 1990, Smucker et al. 2007).

\section{CONCLUSION}

Fire research in the tropics has been geographically clustered, biased to certain landholder types, and limited by a tendency for disciplinary research methods. In this systematic review we have demonstrated how inherent assumptions of disciplinary approaches to fire research may be compromising assessments of a complex coupled system. Furthermore, although traditional research can be used to target certain facets of the fire complex, they should avoid recommending management solutions without clear evidence. To maximize its effectiveness, future research should attempt to integrate the patterns of fire occurrence to the processes of fire use and management. Despite the challenges that arise when trying to bridge scales while maintaining legitimacy (Fox et al. 2003, Seixas 2006), there have been encouraging mixed method contributions to fire research (e.g., Simmons et al. 2004, Dennis et al. 2005). Causes and solutions to tropical forest fires are diverse, and interdisciplinary research designs are needed to improve current understanding and inform sustainable management solutions to extinguish the problem.

Responses to this article can be read online at: http://www.ecologyandsociety.org/vol16/iss 1/art53/ responses/

\section{Acknowledgments:}

We are grateful to the editor, Prof. Carl Folke, and our two anonymous reviewers. We also thank Raoni Rajão, Adrian Southern, Ilya Maclean, and Peter Newton for their comments on the draft manuscript. This research was funded by NERC-ESRC grant ES/ F012500/1, Darwin Initiative grant no. 17-023 and by the Center for International Forestry Research (CIFOR). 


\section{LITERATURE CITED}

Adeney, J. M., N. L. Christensen, and S. L. Pimm. 2009. Reserves protect against deforestation fires in the Amazon. PLoS One 4:e5014.

Aiken, S. R. 2004. Runaway fires, smoke-haze pollution, and unnatural disasters in Indonesia. Geographical Review 94:55-79.

Alencar, A., D. Nepstad, and M. D. V. Diaz. 2006. Forest understory fire in the Brazilian Amazon in ENSO and non-ENSO years: area burned and committed carbon emissions. Earth Interactions 10:1-17.

Alencar, A. A. C., L. A. Solórazano, and D. C. Nepstad. 2004. Modeling forest understory fires in an eastern Amazonian landscape. Ecological Applications Suppl. 14:S139-S149.

Aragão, L., Y. Malhi, N. Barbier, A. Lima, Y. Shimabukuro, L. Anderson, and S. Saatchi. 2008. Interactions between rainfall, deforestation and fires during recent years in the Brazilian Amazonia. Philosophical Transactions of the Royal Society Biological Sciences 363:1779-1785.

Aragão, L., and Y. E. Shimabukuro. 2010. The incidence of fire in Amazonian forests with implications for REDD. Science 328:1275-1278.

Arima, E. Y., C. S. Simmons, R. T. Walker, and M. A. Cochrane. 2007. Fire in the Brazilian Amazon: a spatially explicit model for policy impact analysis. Journal of Regional Science 47:541-567.

Asner, G. P., E. N. Broadbent, P. J. C. Oliveira, M. Keller, D. E. Knapp, and J. N. M. Silva. 2006. Condition and fate of logged forests in the Brazilian Amazon. Proceedings of the National Academy of Sciences of the United States of America 103:12947-12950.

Barlow, J., and C. A. Peres. 2006. Effects of single and recurrent wildfires on fruit production and large vertebrate abundance in a central Amazonian forest. Biodiversity and Conservation 15:985-1012.

Barrera-Bassols, N., J. A. Zinck, and E. Van Ranst. 2006. Symbolism, knowledge and management of soil and land resources in indigenous communities: ethnopedology at global, regional and local scales. Catena 65:118-137.
Barreto, P., C. J. Souza, R. Nogueron, A. Anderson, and R. Salamão. 2006. Human pressure on the Brazilian Amazon forests. World Resources Institute, Belém, Brasil.

Berkes, F. 2004. Rethinking community-based conservation. Conservation Biology 18:621-630.

Berkes, F. 2006. Globalization, roving bandits, and marine resources. Science 312:1472-1472.

Betts, R. A., P. M. Cox, M. Collins, P. P. Harris, C. Huntingford, and C. D. Jones. 2004. The role of ecosystem-atmosphere interactions in simulated Amazonian precipitation decrease and forest dieback under global climate warming. Theoretical and Applied Climatology 78:157-175.

Bird, R. B., D. W. Bird, B. F. Codding, C. H. Parker, and J. H. Jones. 2008. The "fire stick farming" hypothesis: Australian Aboriginal foraging strategies, biodiversity, and anthropogenic fire mosaics. Proceedings of the National Academy of Sciences of the United States of America 105:14796-14801.

Blaikie, N. W. H. 2000. Approaches to social enquiry. Polity, Cambridge, UK.

Bowman, D., J. K. Balch, P. Artaxo, W. J. Bond, J. M. Carlson, M. A. Cochrane, C. M. D'Antonio, R. S. DeFries, J. C. Doyle, S. P. Harrison, F. H. Johnston, J. E. Keeley, M. A. Krawchuk, C. A. Kull, J. B. Marston, M. A. Moritz, I. C. Prentice, C. I. Roos, A. C. Scott, T. W. Swetnam, G. R. van der Werf, and S. J. Pyne. 2009. Fire in the earth system. Science 324:481-484.

Bowman, M. S., G. S. Amacher, and F. D. Merry. 2008. Fire use and prevention by traditional households in the Brazilian Amazon. Ecological Economics 67:117-130.

Boyd, E. 2008. Navigating Amazonia under uncertainty: past, present and future environmental governance. Philosophical Transactions of the Royal Society Biological Sciences 363:1911-1916.

Brady, N. C. 1996. Alternatives to slash-and-burn: a global imperative. Agriculture Ecosystems \& Environment 58:3-11.

Brondizio, E. S., and E. F. Moran. 2008. Human dimensions of climate change: the vulnerability of small farmers in the Amazon. Philosophical 
Transactions of the Royal Society B-Biological Sciences 363:1803-1809.

Bruner, A. G., R. E. Gullison, R. E. Rice, and G. A. B. da Fonseca. 2001. Effectiveness of parks in protecting tropical biodiversity. Science 291:125-128.

Bucini, G., and E. F. Lambin. 2002. Fire impacts on vegetation in Central Africa: a remote-sensingbased statistical analysis. Applied Geography 22:27-48.

Cardoso, M. F., G. C. Hurtt, B. Moore, C. A. Nobre, and E. M. Prins. 2003. Projecting future fire activity in Amazonia. Global Change Biology 9:656-669.

Carvelheiro, K. 2004. Community fire management in the Marana region, Brazilian Amazonia. Dissertation. University of Florida, Gainesville, Florida, USA.

Caviglia-Harris, J. L., and D. W. Harris. 2008. Integrating survey and remote sensing data to analyze land use at a fine scale: insights from agricultural households in the Brazilian Amazon. International Regional Science Review 31:115-137.

Chand, T. R. K., K. V. Badarinath, V. K. Prasad, M. S. R. Murthy, C. D. Elvidge, and B. T. Tuttle. 2006. Monitoring forest fires over the Indian region using Defense Meteorological Satellite Program-Operational Linescan System nighttime satellite data. Remote Sensing of Environment 103:165-178.

Chokkalingam, U., I. Kurniawan, and Y. Ruchiat. 2005. Fire, livelihoods, and environmental change in the Middle Mahakam peatlands, East Kalimantan. Ecology and Society 10(1): 26. [online] URL: http://www.ecologyandsociety.org/vol10/iss1/ art26/.

Chokkalingam, U., Suyanto, R. P. Permana, I. Kurniawan, J. Mannes, A. Darmawan, N. Khususyiah, and R. H. Susanto. 2007. Community fire use, resource change, and livelihood impacts: the downward spiral in the wetlands of southern Sumatra. Mitigation and Adaptation Strategies for Global Change 12:75-100.

Cochrane, M. A. 2001. Synergistic interactions between habitat fragmentation and fire in evergreen tropical forests. Conservation Biology 15:1515-1521.
Cochrane, M. A., and W. F. Laurance. 2008. Synergisms among fire, land use, and climate change in the Amazon. Ambio 37:522-527.

Crawley, M. J. 2007. The $R$ book. John Wiley \& Sons, Chichester, UK.

Crews, K. A., and S. J. Walsh. 2009. Remote sensing and the social sciences. Pages 437-445 in T. A. Warner, D. M. Nellis, and G. M. Foody, editors. The SAGE handbook of remote sensing. SAGE, London, UK.

de Mendonça, M. J. C., M. D. V. Diaz, D. Nepstad, R. S. da Motta, A. Alencar, J. C. Gomes, and R. A. Ortiz. 2004. The economic cost of the use of fire in the Amazon. Ecological Economics 49:89-105.

Dennis, R. A., J. Mayer, G. Applegate, U. Chokkalingam, C. J. P. Colfer, I. Kurniawan, H. Lachowski, P. Maus, R. P. Permana, Y. Ruchiat, F. Stolle, Suyanto, and T. P. Tomich. 2005. Fire, people and pixels: Linking social science and remote sensing to understand underlying causes and impacts of fires in Indonesia. Human Ecology 33:465-504.

Dymond, C. C., R. D. Field, O. Roswintiarti, and Guswanto. 2005. Using satellite fire detection to calibrate components of the Fire Weather Index system in Malaysia and Indonesia. Environmental Management 35:426-440.

Elvidge, C. D., V. R. Hobson, K. E. Baugh, J. B. Dietz, Y. E. Shimabukuro, T. Krug, E. Novo, and F. R. Echavarria. 2001. DMSP-OLS estimation of tropical forest area impacted by surface fires in Roraima, Brazil: 1995 versus 1998. International Journal of Remote Sensing 22:2661-2673.

Eva, H., and E. F. Lambin. 2000. Fires and landcover change in the tropics: a remote sensing analysis at the landscape scale. Journal of Biogeography 27:765-776.

Fearnside, P. M. 2005. Deforestation in Brazilian Amazonia: History, rates, and consequences. Conservation Biology 19:680-688.

Flannigan, M. D., M. A. Krawchuk, W. J. de Groot, B. M. Wotton, and L. M. Gowman. 2009. 
Implications of changing climate for global wildland fire. International Journal of Wildland Fire 18:483-507.

Foley, J. A., G. P. Asner, M. H. Costa, M. T. Coe, R. DeFries, H. K. Gibbs, E. A. Howard, S. Olson, J. Patz, N. Ramankutty, and P. Snyder. 2007. Amazonia revealed: forest degradation and loss of ecosystem goods and services in the Amazon Basin. Frontiers in Ecology and the Environment 5:25-32.

Folke, C., T. Hahn, P. Olsson, and J. Norberg. 2005. Adaptive governance of social-ecological systems. Annual Review of Environment and Resources 30:441-473.

Fox, J., R. R. Rindfuss, S. J. Walsh, and V. Mishra, editors. 2003. People and the environment: Approaches to linking household and community surveys to remote sensing and GIS. Kluwer Academic, Norwell, Massachusetts, USA.

Frost, P., B. Campbell, G. Medina, and L. Usongo. 2006. Landscape-scale approaches for integrated natural resource management in tropical forest landscapes. Ecology and Society 11(2): 30. [online] URL: http://www.ecologyandsociety.org/vol11/iss2/ art30/.

Giest, H. J., and E. F. Lambin. 2001. What drives tropical deforestation? A meta-analysis of proximate and underlying causes of deforestation based on subnational case study evidence. LUCC International Project Office, University of Louvain, Louvain-la-Neuve, Belgium.

Giri, C., and S. Shrestha. 2000. Forest fire mapping in Huay Kha Khaeng Wildlife Sanctuary, Thailand. International Journal of Remote Sensing 21:2023-2030.

Harwell, E. 2000. Remote sensibilities: discourses of technology and the making of Indonesia's natural disaster. Development and Change 31:307-340.

Hayes, N., and R. Rajão. 2011. Competing institutional logics and sustainable development: the case of geographic information systems in Brazil's Amazon region. Information Technology for Development 17:4-23.

Hoare, P. 2004. A process for community and government cooperation to reduce the forest fire and smoke problem in Thailand. Agriculture Ecosystems \& Environment 104:35-46.
Instituto Nacional de Pesquisas Espaciais (INPE). 2009. Sistema DETER: Deteção de desmatamento em tempo real. Ministério da Ciência e Tecnologia, Brasilía, Brasil. [online] URL: http://www.obt.inpe. br/deter/.

Intergovernmental Panel on Climate Change (IPCC). 2007. Climate Change 2007: mitigation of climate change. Contribution of Working Group III to the Fourth Assessment Report of the Intergovernmental Panel on Climate Change. B. Metz, O. R. Davidson, P. R. Bosch, R. Dave, and L. A. Meyer, editors. Cambridge University Press, Cambridge, UK.

Jick, T. D. 1979. Mixing qualitative and quantitative methods - triangulation in action. Administrative Science Quarterly 24:602-611.

Johnson, R. B., A. J. Onwuegbuzie, and L. A. Turner. 2007. Toward a definition of mixed methods research. Journal of Mixed Methods Research 1:112-133.

Kant, Y., V. K. Prasad, and K. V. S. Badarinath. 2000. Algorithm for detection of active fire zones using NOAA AVHRR data. Infrared Physics \& Technology 41:29-34.

Kates, R. W., and T. J. Wilbanks. 2003. Making the global local: responding to climate change concerns from the ground up. Environment 45:12-23.

Kull, C. A. 2002c. Empowering pyromaniacs in Madagascar: ideology and legitimacy in communitybased natural resource management. Development and Change 33:57-78.

Kull, C. A. 2002a. Madagascar's burning issue: the persistent conflict over fire. Environment 44:8-19.

Kull, C. A. 2002b. Madagascar aflame: landscape burning as peasant protest, resistance, or a resource management tool? Political Geography 21:927-953.

Liu, J. G., T. Dietz, S. R. Carpenter, M. Alberti, C. Folke, E. Moran, A. N. Pell, P. Deadman, T. Kratz, J. Lubchenco, E. Ostrom, Z. Ouyang, W. Provencher, C. L. Redman, S. H. Schneider, and W. W. Taylor. 2007. Complexity of coupled human and natural systems. Science 317:1513-1516.

Liverman, D., E. Moran, R. R. Rindfuss, and P. C. Stern, editors. 1998. People and pixels: linking 
remote sensing and social science. National Academy Press, Washington, D.C., USA.

Lohman, D. J., D. Bickford, and N. S. Sodhi. 2007. The burning issue. Science 316:376.

Malingreau, J. P., G. Stephens, and L. Fellows. 1985. Remote-sensing of forest fires - Kalimantan and north Borneo in 1982-1983. Ambio 14:314-321.

Malingreau, J. P., and C. J. Tucker. 1988. Largescale deforestation in the southeastern Amazon basin of Brazil. Ambio 17:49-55.

McCracken, S. D., E. S. Brondizio, D. Nelson, E. F. Moran, A. D. Siqueira, and C. RodriguezPedraza. 1999. Remote sensing and GIS at farm property level: demography and deforestation in the Brazilian Amazon. Photogrammetric Engineering and Remote Sensing 65:1311-1320.

McGregor, S., V. Lawson, P. Christophersen, R. Kennett, J. Boyden, P. Bayliss, A. Liedloff, B. McKaige, and A. N. Andersen. 2010. Indigenous wetland burning: conserving natural and cultural resources in Australia's World Heritage-listed Kakadu National Park. Human Ecology 38:721-729.

Mistry, J. 1998. Decision-making for fire use among farmers in savannas: an exploratory study in the Distrito Federal, central Brazil. Journal of Environmental Management 54:321-334.

Murdiyarso, D., and L. Lebel. 2007. Local to global perspectives on forest and land fires in Southeast Asia. Mitigation and Adaptation Strategies for Global Change 12:3-11.

Murdiyarso, D., L. Lebel, A. N. Gintings, S. M. H. Tampubolon, A. Heil, and M. Wasson. 2004. Policy responses to complex environmental problems: insights from a science-policy activity on transboundary haze from vegetation fires in Southeast Asia. Agriculture Ecosystems \& Environment 104:47-56.

Nepstad, D., G. Carvalho, A. C. Barros, A. Alencar, J. P. Capobianco, J. Bishop, P. Moutinho, P. Lefebvre, U. L. Silva, and E. Prins. 2001. Road paving, fire regime feedbacks, and the future of Amazon forests. Forest Ecology and Management 154:395-407.
Nepstad, D., A. Moreira, and A. Alencar. 1999a. A Floresta em Chamas: Origens, Impactos $e$ Prevenção do fogo na Amazônia. IPAM \& WHRC Brasília, Brasil.

Nepstad, D., S. Schwartzman, B. Bamberger, M. Santilli, D. Ray, P. Schlesinger, P. Lefebvre, A. Alencar, E. Prinz, G. Fiske, and A. Rolla. 2006. Inhibition of Amazon deforestation and fire by parks and indigenous lands. Conservation Biology 20:65-73.

Nepstad, D. C., A. Verissimo, A. Alencar, C. Nobre, E. Lima, P. Lefebvre, P. Schlesinger, C. Potter, P. Moutinho, E. Mendoza, M. Cochrane, and V. Brooks. 1999b. Large-scale impoverishment of Amazonian forests by logging and fire. Nature 398:505-508.

Olsen, W. 2004. Triangulation in social research: qualitative and quantitative methods can really be mixed. In M. Holborn, editor. Developments in sociology. Causeway Press, Ormskirk, UK.

Olsson, P., L. H. Gunderson, S. R. Carpenter, P. Ryan, L. Lebel, C. Folke, and C. S. Holling. 2006. Shooting the rapids: navigating transitions to adaptive governance of social-ecological systems. Ecology and Society 11(1): 18. [online] URL: http: //www.ecologyandsociety.org/vol11/iss1/art18/.

Ostrom, E. 1990. Governing the commons: the evolution of institutions for collective action. Cambridge University Press, Cambridge, UK.

Ostrom, E. 2007. A diagnostic approach for going beyond panaceas. Proceedings of the National Academy of Sciences of the United States of America 104:15181-15187.

Ostrom, E., M. A. Janssen, and J. M. Anderies. 2007. Going beyond panaceas. Proceedings of the National Academy of Sciences of the United States of America 104:15176-15178.

Ostrom, E., and H. Nagendra. 2006. Insights on linking forests, trees, and people from the air, on the ground, and in the laboratory. Proceedings of the National Academy of Sciences of the United States of America 103:19224-19231.

Pagdee, A., Y. S. Kim, and P. J. Daugherty. 2006. What makes community forest management 
successful: a meta-study from community forests throughout the world. Society \& Natural Resources 19:33-52.

Pan, W. K. Y., S. J. Walsh, R. E. Bilsborrow, B. G. Frizzelle, C. M. Erlien, and F. Baquero. 2004. Farmlevel models of spatial patterns of land use and land cover dynamics in the Ecuadorian Amazon. Agriculture Ecosystems \& Environment 101:117-134.

Perz, S. G., and R. T. Walker. 2002. Household life cycles and secondary forest cover among small farm colonists in the Amazon. World Development 30:1009-1027.

Phua, M. H., S. Tsuyuki, J. S. Lee, and H. Sasakawa. 2007. Detection of burned peat swamp forest in a heterogeneous tropical landscape: a case study of the Klias Peninsula, Sabah, Malaysia. Landscape and Urban Planning 82:103-116.

Pichon, F. J. 1997. Settler households and land-use patterns in the Amazon frontier: farm-level evidence from Ecuador. World Development 25:67-91.

Posey, D. A. 1985. Indigenous management of tropical forest ecosystems: the case of the Kayapo Indians of the Brazilian Amazon. Agroforestry Systems 3:139-158.

Prasad, V. K., K. S. Badarinath, and A. Eaturu. 2008. Biophysical and anthropogenic controls of forest fires in the Deccan Plateau, India. Journal of Environmental Management 86:1-13.

Pullin, A. S., and G. B. Stewart. 2006. Guidelines for systematic review in conservation and environmental management. Conservation Biology 20:1647-1656.

Pyne, S. J. 2001. Fire: a brief history. Univeristy of Washington Press, Seattle, Washington, USA.

Rajão, R., and N. Hayes. 2009. Conceptions of control and IT artefacts: an institutional account of the Amazon rainforest monitoring system. Journal of Information Technology 24:320-331.

Reid, W. V., F. Berkes, T. Wilbanks, and D. Capistrano, editors. 2006. Bridging scales and knowledge systems: concepts and applications in ecosystem assessment. Island Press, Washington, D. C., USA.
Rindfuss, R. R., S. J. Walsh, V. Mishra, J. Fox, and G. P. Dolcemascolo. 2003. Linking household and remotely sensed data: methodological and practical problems. Pages 1-30 in J. Fox, R. R. Rindfuss, S. J. Walsh, and V. Mishra, editors. People and the environment: approaches for linking household and community surveys to remote sensing and GIS. Kluwer Academic, Norwell, Massachussets, USA.

Roman-Cuesta, R. M., M. Gracia, and J. Retana. 2003. Environmental and human factors influencing fire trends in enso and non-enso years in tropical Mexico. Ecological Applications 13:1177-1192.

Roman-Cuesta, R. M., and J. Martinez-Vilalta. 2006. Effectiveness of protected areas in mitigating fire within their boundaries: case study of Chiapas, Mexico. Conservation Biology 20:1074-1086.

Rudel, T. K. 2008. Meta-analyses of case studies: a method for studying regional and global environmental change. Global Environmental Change-Human and Policy Dimensions 18:18-25.

Seixas, C. S. 2006. Barriers to local level ecosystem assessment and participatory management in Brazil. Pages 255-274 in W. V. Reid, F. Berkes, T. Wilbanks, and D. Capistrano, editors. Bridging scales and knowledge systems: concepts and applications in ecosystem assessment. Island Press, Washington, D.C., USA.

Simmons, C. S., R. T. Walker, C. H. Wood, E. Arima, and M. Cochrane. 2004. Wildfires in Amazonia: a pilot study examining the role of farming systems, social capital, and fire contagion. Journal of Latin American Geography 3:81-95.

Slik, J. W. F., R. W. Verburg, and P. J. A. Kessler. 2002. Effects of fire and selective logging on the tree species composition of lowland dipterocarp forest in East Kalimantan, Indonesia. Biodiversity and Conservation 11:85-98.

Smucker, T. A., D. J. Campbell, J. M. Olson, and E. E. Wangui. 2007. Contemporary challenges of participatory field research for land use change analyses: examples from Kenya. Field Methods 19:384-406.

Sorrensen, C. 2000. Linking smallholder land use and fire activity: examining biomass burning in the 
Brazilian Lower Amazon. Forest Ecology and Management 128:11-25.

Sorrensen, C. 2002. Frontier spaces of vulnerability: Regional change, urbanization, drought and fire hazard in Santarem, Para, Brazil. Urban Ecosystems 16:123-144.

Sorrensen, C. 2004. Contributions of fire use study to land use/cover change frameworks: understanding landscape change in agricultural frontiers. Human Ecology 32:395-419.

Sorrensen, C. 2009. Potential hazards of land policy: conservation, rural development and fire use in the Brazilian Amazon. Land Use Policy 26:782-791.

Stolle, F., K. M. Chomitz, E. F. Lambin, and T. P. Tomich. 2003. Land use and vegetation fires in Jambi Province, Sumatra, Indonesia. Forest Ecology and Management 179:277-292.

Stolle, F., R. A. Dennis, I. Kurniwan, and E. F. Lambin. 2004. Evaluation of remote sensing-based active fire datasets in Indonesia. International Journal of Remote Sensing 25:471-479.

Stolle, F., and E. F. Lambin. 2003. Interprovincial and interannual differences in the causes of landuse fires in Sumatra, Indonesia. Environmental Conservation 30:375-387.

Suyanto, S. 2007. Underlying cause of fire: different form of land tenure conflicts in Sumatra. Mitigation and Adaptation Strategies for Global Change 12:75-100.

Suyanto, S., R. P. Permana, N. Khususiyah, and L. Joshi. 2005. Land tenure, agroforestry adoption, and reduction of fire hazard in a forest zone: a case study from Lampung, Sumatra, Indonesia. Agroforestry Systems 65:1-11.

Tacconi, L., P. F. Moore, and D. Kaimowitz. 2007. Fires in tropical forests - what is really the problem? Lessons from Indonesia. Mitigation and Adaptation Strategies for Global Change 12:55-66.

Tacconi, L., and Y. Ruchiat. 2006. Livelihoods, fire and policy in eastern Indonesia. Singapore Journal of Tropical Geography 27:67-81.

Toniolo, M. A. 2004. The role of land tenure in the occurrence of accidental fires in the Amazon region: case studies from the national forest of Tapajos, Para, Brazil. Thesis. Indiana University, Bloomington, Indiana, USA.

Turner, B. L., E. F. Lambin, and A. Reenberg. 2007. The emergence of land change science for global environmental change and sustainability. Proceedings of the National Academy of Sciences of the United States of America 104:20666-20671.

Uhl, C., and R. Buschbacher. 1985. A disturbing synergism between cattle ranching practices and selective tree harvesting in the Eastern Amazon. Biotropica 17:265-268.

Vadrevu, K. P., K. V. S. Badarinath, and E. Anuradha. 2008. Spatial patterns in vegetation fires in the Indian region. Environmental Monitoring and Assessment 147:1-13.

Varma, A. 2003. The economics of slash and burn: a case study of the 1997-1998 Indonesian forest fires. Ecological Economics 46:159-171.

Vayda, A. P. 2006. Causal explanation of Indonesian forest fires: concepts, applications, and research priorities. Human Ecology 34:615-635.

Walker, R., E. Moran, and L. Anselin. 2000. Deforestation and cattle ranching in the Brazilian Amazon: external capital and household processes. World Development 28:683-699.

Walsh, S. J., J. P. Messina, C. F. Mena, G. P. Malanson, and P. H. Page. 2008. Complexity theory, spatial simulation models, and land use dynamics in the Northern Ecuadorian Amazon. Geoforum 39:867-878.

Wilbanks, T. 2006. How scale matters: some concepts and findings. Pages 21-36 in W. V. Reid, F. Berkes, T. Wilbanks, and D. Capistrano, editors. Bridging scales and knowledge systems: concepts and applications in ecosystem assessment. Island Press, Washington, D.C., USA.

Wood, C. H., and D. Skole. 1998. Linking satellite, census, and survey data to study deforestation in the Brazilian Amazon. Pages 70-93 in D. Liverman, E. Moran, R. R. Rindfuss, and P. C. Stern, editors. People and pixels: linking remote sensing and social science. National Academy Press, Washington, D. C., USA. 
Wright, S. J., G. A. Sanchez-Azofeifa, C. PortilloQuintero, and D. Davies. 2007. Poverty and corruption compromise tropical forest reserves. Ecological Applications 17:1259-1266. 


\section{APPENDIX 1. Variables that constitute each of the categories used in the review.}

(SP - socio-political; C - climatic; FTQ - forest type and quality; E - economic; L - landscape context; TR - technological and research; FM - direct fire management; FC - fire characteristics) used in the review.

Category (abbreviation)

Socio-political (SP)
Climatic (C)

Forest type and quality (FTQ)
Variables

Community cohesion, kinship, homogeneity

Community designation

Community institutional capacity

Conservation and development tradeoffs

Corruption perception index (CPI)

Corruption, power capture

Definition of community area of administration

Devolution of natural resource management, incorporation of traditional ecological knowledge

Distant policy influence

Environmental education and public awareness, science-policy discourse

Fire legislation

Government enforcement of fire, land use legislation

Guards per $\mathrm{km}^{2}$

Human development index (HDI)

Inputs to reduce dependence on fire

International aid to support shift to non-fire agriculture

Labor

Land tenure security

Local perceptions of fire, of climate and of blame

Long term policy solutions

Outmigration and increasing turnover

Park boundaries

Participatory planning for natural resource management

Political and ideological conflict between state and local actors' perception of fire

Political conflict at state-level

Population density

Reserve status

Sanctions

Social injustice

Staff resources and information availability in reserves

State institutional capacity

State/province membership

Support from international community

Time on plot

Transmigration project presence

Unfair resource access

Village level rules

Climate change

Drought

Humidity

Rainfall

Season

Temperature

Wind speed

Year

Biomass density

Designated conversion area

Designated production area

Forest degradation

Forest management

Fragment degradation

Logging

Suitability for rubber

Vegetation type 
Landscape context (LC)

Economic (E)

Technological and research (TR)

Fire management (FM)

Fire characteristics (FC)
Deforestation

Distance to charcoal pit

Distance to populated place

Distance to river

Distance to smallholder

Edge per cell

Elevation

Fragment shape

Fragment size

Fundamental change in land management

Land-cover change

Large landholder zone

Percent of neighboring cells in cattle pasture

Road accessibility

Soil characteristics

Compensation availability

Economic incentives

Gross domestic product (GDP) per capita, per $\mathrm{km}^{2}$

Size of cattle herds

Market availability

Needs of the local poor

Risk of loss to accidental fire

Poverty

Price of beef

Price of soy

Actor specific research

Agricultural alternatives to fire use

Algorithm properties

Available data

Communication system

Degree to which research is standardized

El Nino research

Fire modeling research

Information on previously burnt areas

Inter-reserve research

Mixed-method research

Reliance on geospatial technologies

Research location

Satellite and monitoring techniques

Science-policy interaction

State of fine-scale meteorological data

State of local-level research

State of research on biophysical properties of fire

State of research on cost and benefits of fire

State of research on human-dimensions of fire

State of research on policy options

Support and access to and state of information regarding

ENSO

Uncertainty

Community level fire management

Farmers and ranchers fire management

Fire management plans

Fire safety training

Preparedness

Targeted fire management

Burn pattern

Fire regime characteristics

Fire return interval

Qualities of fire (e.g. anonymity, self-propagation) 